\title{
Clinical Presentation of Pott's disease of the Spine in Adult Sudanese Patients
}

Elbashir G Ahmed ${ }^{1}$, Nour Eldaim E Elbadawi ${ }^{2}$, Elwathiq K Ibrahim $^{3}$ and Mamoun M Mohammed ${ }^{4}$

${ }^{1}$ Department of Medicine, Faculty of Medicine \& Health Sciences, University of Kassala, Sudan

${ }^{2}$ Department of Biochemistry, Faculty of Medicine \& Health Sciences, University of Kassala, Sudan

${ }^{3}$ Department of Anatomy, Faculty of Medicine \& Health Sciences, University of Kassala, Sudan

${ }^{4}$ Department of Microbiology, Faculty of Medicine \& Health Sciences, University of Kassala, Sudan

\begin{abstract}
Tuberculosis (TB) of the spine (Pott's disease) is the commonest and most dangerous form of skeletal TB. Delay in establishing diagnosis and management can cause spinal cord compression and spinal deformity resulting in serious neurological deficit and bad prognosis. This was a prospective hospital-based study investigating the data on hundred cases of Pott's disease presented to Khartoum Teaching Hospital during the period from 2008 to 2010. 60 patients were females and 40 were males. The mean age of our patients was \pm 41 . The course of the disease was progressive and of gradual onset in the majority of the cases. $76 \%$ of our study group was presented with neurological deficits ranging from lower limb anesthesia, numbness, trunk weakness, root pain, muscle pain and flexion spasm.
\end{abstract}

Keywords: Pott's disease; Spine; Adult; Sudanese patients

\section{Introduction}

Spinal TB (Pott's disease) and surgical management of its main complication, the para vertebaral abscess was firstly described in 1782 by the English surgeon Sir Percival Pott [1]. Recent molecular studies on mycobacterial DNA demonstrated TB infection in the old spinal remains of the ancient Egyptian mummies and the Iron Age [2,3].

Spinal TB is commonest type of tuberculosis involving the bony elements. It comprises almost of half of cases of the skeletal TB [4]. Approximately $1-2 \%$ of total tuberculosis cases are attributable to Pott's disease [5].

Many factors affect the clinical presentation of Pott's disease. These include; the clinical stage of the disease, the site of spine involved in the disease process and the presence of absence of complications, like neurologic deficits, paravertebral abscesses and sinuses [6].

The classical presentation of Pott's disease of the spine is the spondylodiscitis, which is a combination of vertebral osteomyelitis, spondylitis and discitis associated with destruction of two or more contiguous segments of the spine with or without paraspinal mass [7].

The aim of this study is to describe the various clinical presentations of Pott's disease of the spine among Sudanese patients and to provide important comparative data of the disease for both clinicians and researchers.

\section{Patients and Methods}

This study was a cross-sectional hospital-based study conducted at Khartoum Teaching Hospital and Shaab Teaching Hospital during the period from 2008 to 2010 . Hundred patients were enrolled in the study. Written consent was obtained from the patients participated in the study. A pretested questionnaire was designed to include demographic data, history of the disease, and examination of different systems with emphasis on the CNS. Haematological investigations, imaging studies including plain X ray, CT scan, and myelography were done to detect the distribution of the disease among different regions of the spines. Biopsies were taken from some patients as appropriate and sent for histopathologic examination. Data obtained were statistically analyzed using Statistical Package for Social Sciences (SPSS) version 11.

\section{Results}

In this study, hundred patients with Pott's disease of the spine were recruited. 60 patients (60\%) were females and 40 patients (40\%) were males. The majority of the patients fall in the age group 45-54 years, which constituted 25 cases (25\%) of the study group, followed by the age group 15-24 years, 22 cases (22\%). The groups 65-74, 35-44 and 25 -34 constitute 20 cases (20\%), 18 cases (18\%) and 15 cases (15\%) respectively (Table 1). The mean age of presentation in our study was 41 years. In 36 patients (36\%), Pott's disease was found in association with pulmonary tuberculosis. The main complaint in the whole study group was backache and lower limb weakness. The course of the disease was progressive. In 92 patients (92\%), the onset was gradual. 87 patients (87\%) said that they had experienced weight loss, where 74 patients (74\%) had mild fever. $76 \%$ of patients presented with neurological deficits. Lower limb anaesthesia was seen in 72 patients (72\%) and numbness in 70 patients (70\%) of the whole group. 46 patients (46\%) presented with weakness of the trunk, whereas 44 patients $(44 \%)$

\begin{tabular}{|l|l|l|}
\hline Age Group & Frequency & $\%$ \\
\hline $15-24$ & 22 & 22 \\
\hline $25-34$ & 15 & 15 \\
\hline $35-44$ & 18 & 18 \\
\hline $45-54$ & 25 & 25 \\
\hline $65-74$ & 20 & 20 \\
\hline Total & 100 & 100 \\
\hline
\end{tabular}

Table 1: Age groups and their frequencies in the patients enrolled in the study.

${ }^{*}$ Corresponding author: NourEldaim Elnoman Elbadawi, Department of Biochemistry, Faculty of Medicine \& Health Sciences, University of Kassala, Kassala, Sudan, E-mail: noureldaim@hotmail.com

Received January 26, 2013; Accepted February 28, 2013; Published March 04 2013

Citation: Ahmed EG, Elbadawi NEE, Ibrahim EK, Mohammed MM (2013) Clinical Presentation of Pott's disease of the Spine in Adult Sudanese Patients. J Med Microb Diagn 2: 120. doi:10.4172/2161-0703.1000120

Copyright: (c) 2013 Ahmed EG, et al. This is an open-access article distributed under the terms of the Creative Commons Attribution License, which permits unrestricted use, distribution, and reproduction in any medium, provided the original author and source are credited. 


\begin{tabular}{|l|l|l|}
\hline Symptom & Frequency & $\%$ \\
\hline Lower limb anaesthesia & 72 & 72 \\
\hline Lower limb numbness & 70 & 70 \\
\hline Trunk weakness & 46 & 46 \\
\hline Root pain & 44 & 44 \\
\hline Muscle pain & 22 & 22 \\
\hline Flexion spasm & 16 & 16 \\
\hline Feet hyperasthesia & 4 & 4 \\
\hline
\end{tabular}

Table 2: Types and frequencies of neurological symptoms developed among the study group.

complained of root pain. Muscle pain was noted in 22 patients $(22 \%)$ and flexion spasm in 16 patients (16\%). Only four patients (4\%) complained hyperaesthesia of the feet, (Table 2).

\section{Discussion}

Spinal TB, the second most common presentation of Extrapulmonary Tuberculosis (EPTB), can cause significant morbidity and often poses diagnostic challenges to clinicians [8]. Pott's disease can result from direct spread through lymphatic drainage from another focus of infection, intracanalicular spread, or direct invasion during bacteremic stage of the disease [9]. The mean age of examined sample in our study is higher than that of the Nigerian sample of the study conducted by Motsitsi and Chipeta, but their sample was much smaller [10]. Fever and weight loss are amongst the constitutional symptoms of Pott's disease.

A history of gradual onset and slow progression in the majority of our cases suggests chronicity of the disease, a characteristic of tuberculosis [11]. The reported average duration of symptoms at diagnosis is four months; but can be considerably longer [12].

The first and most common clinical symptom of Pott's disease is the back pain, followed with fever [13].

In a review series of 1,997 patients with Pott's disease, back pain was found to be most commonly reported symptom and the disease affects mainly the thoracic spine [5]. Kyphotic deformity, spinal instability and neurological deficit are the common complications associated with Pott's disease [14]. Signs of neurologic deficits depend on the level of spinal cord or nerve root involved. Depending on the degree of spinal cord involvement and spinal root compression, those deficits were range from single nerve palsy to hemiparesis, paraplegia or quadriplegia.

In the majority of African patients with non-traumatic paraplegia, spinal TB was found to the cause. Neurological deficits were seen in $76 \%$ of our cases, this is the lowest proportion in compared to the figures reported in world literature $[15,16]$.

Active stage of Pott's disease of the spine is frequently associated with neurological deficits due to mechanical compression with granuloma, instability of vertebral segments and inflammatory changes of spinal elements. Longstanding kyphosis with compression of the spinal cord might be responsible for neurological complications after healing of the disease process [17].

Neurological deficits without bony involvement may be due to direct invasion of the spinal canal and spinal cord with extradural or intradural tuberculomas or tuberculous arachnoiditis [18]

\section{References}

1. Pott $P$ (2002) The chirurgical works of Percivall Pott, F.R.S., surgeon to St Bartholomew's Hospital, a new edition, with his last corrections. 1808. Clin Orthop Relat Res 4-10.
2. Zink A, Haas CJ, Reischl U, Szeimies U, Nerlich AG (2001) Molecular analysis of skeletal tuberculosis in an ancient Egyptian population. J Med Microbiol 50 355-366.

3. Taylor GM, Murphy E, Hopkins R, Rutland P, Chistov Y (2007) First report of Mycobacterium bovis DNA in human remains from the Iron Age. Microbiology 53: $1243-1249$.

4. Moore SL, Rafii M (2001) Imaging of musculoskeletal and spinal tuberculosis. Radiol Clin North Am 39: 329-342.

5. Beek LA, van der Werf MJ, Richter C, Borgdorff MW (2006) Extrapulmonary tuberculosis by nationality, The Netherlands, 1993-2001. Emerg Infect Dis 12: 1375-1382.

6. Ferrer MF, Torres LG, Ramírez OA, Zarzuelo MR, Del Prado González N (2012) Tuberculosis of the spine. A systematic review of case series. Int Orthop 36 221-231.

7. Pertuiset E, Beaudreuil J, Lioté F, Horusitzky A, Kemiche F, et al. (1999) Spinal tuberculosis in adults. A study of 103 cases in a developed country, 1980-1994. Medicine 78: 309-320.

8. Desai SS (1994) Early diagnosis of spinal tuberculosis by MRI. J Bone Joint Surg $\mathrm{Br} 76:$ 863-869.

9. Mankin HJ, Wu HC (1996) Weekly clinicopathological exercises: case 9-1996: a 21-year-old African woman with thoracolumbar pain and fever. N Engl J Med 334: 784-789.

10. Motsitsi NS, Chipeta M (2007) Prognosis of Spinal Tuberculosis. Journal of Orthopedic Surgery 4.

11. Pola E, Rossi B, Nasto LA, Colangelo D, Logroscino CA (2012) Surgical treatment of tuberculous spondylodiscitis. Eur Rev Med Pharmacol Sci 16: 7985.

12. Le Page L, Feydy A, Rillardon L, Dufour V, Le Hénanff A, et al. (2006) Spinal tuberculosis: a longitudinal study with clinical, laboratory, and imaging outcomes. Semin Arthritis Rheum 36: 124-129.

13. Sinan T, Al-Khawari H, Ismail M, Ben-Nakhi A, Sheikh M (2004) Spinal tuberculosis: CT and MRI feature. Ann Saudi Med 24: 437-441.

14. Akinyoola AL, Adegbehingbe OO, Ashaleye CM (2007) Tuberculosis Of The Spine In Nigeria: Has Anything Changed? The Internet Journal of Third World Medicine 4.

15. Turgut M (2001) Spinal tuberculosis (Pott's disease): its clinical presentation, surgical management, and outcome. A survey study on 694 patients. Neurosurg Rev 24: 8-13.

16. Dursun AB, Güler ZM, Budak K, Ceylan O, Ataş E (2003) Pott's disease and different clinical presentations Pott's disease and different clinical presentations. Tuberk Toraks 51: 416-423.

17. Jain AK, Kumar J (2012) Tuberculosis of spine: neurological deficit. Eur Spine J.

18. Lifeso RM, Weaver P, Harder EH (1985) Tuberculous spondylitis in adults. J Bone Joint Surg Am 67: 1405-1413. 